\title{
ANAK ZINA DALAM PANDANGAN ISLAM
}

\author{
Oleh: \\ Moh. Ali Ghafir ${ }^{1}$ \\ Email: lazsidogiri_bangkalan@yahoo.com
}

\begin{abstract}
Adultery is a child born of a mother resulting from a relationship that does not follow the rules of syara' or the outcome of a forbidden relationship. Children resulting from unmarried relationships, have the same degree in the sight of Allah as the other servants. He is very likely to be a happy person in the world and in the hereafter if he can actualize himself to be a pious person. An illegitimate child is a servant of God who must be respected, he has no difference with the other servants of God. It's just that he was born of irresponsible people. In this case the sin is both perpetrators. Babies who are born will not bear the slightest sin of committing adultery.
\end{abstract}

Keywords: adultery, Islam view

\section{Pendahuluan}

Pergaulan yang semakin bebas, dan perkembangan tehnologi yang tidak bisa terbendung terdapat banyak dampak negatif bagi generasi muda. Pendidikan agama dan akhlaq semakin tidak digemari. Pantauan dari orang tua sudah kurang maksimal. Para dai, ustadz, guru dan kiai yang selalu mengajak pada jalan kebenaran haaqnya terkewatkan begitu saja. Akhirnya banyak generasi muda yang tersesat dari jalan yang benar. Tidak sedikit anak-anak harapan bangsa hamil diluar nikah dan melahirkan seorang anak yang disebut dengan anak zina. Jalan satusatunya untuk menutupi aib yang mereka lakukan dengan cara membuang anak yang tak berdosa itu.

${ }^{1}$ Dosen STAI Syaichona Moh. Cholil Bangkalan 
Islam merupakan agama rahmatan li al-alamin bagi semua pemeluknya. Semua pemeluk berpeluang untuk menjadi orang yang mulia di sisi Allah SWT, tergantung dari nilai ketaqwaan yang mereka miliki, dengan tanpa memandang anak siapa dan dari suku apa. Semakin banyak ibadah yang dilakukan, maka ia akan menjadi hamba Allah SWT pilihan. Dan bagi hamba yang banyak melakukan dosa, ia akan menjadi hamba yang hina di sisi Allah SWT.

Anak zina adalah salah satu hamba Allah SWT yang berpeluang juga menjadi orang yang bahagia di dunia dan akhirat. Pada saat masih hidup harus menjadi orang yang terhormat sebagaimana hamba Allah yang lain. Ia masih punya harga diri dan bisa mengaktualisasikan diri, dan menjadi orang yang terbaik.

\section{Tentang Anak Zina}

Pada zaman sekarang ini, banyak ditemui kejadian anak yang dibuang oleh orang tuanya di berbagai tempat, seperti: pembuangan sampah, sungai, pinggir jalan, rumah sakit, bahkan di mushalla dan masjid. Kejadian ini terus meningkat sebagai akibat dari perilaku seks bebas yang mengakibatkan kehamilan di luar pernikahan yang sah. Anak itu sengaja dibuang oleh oknum yang tidak bertanggung jawab. Status anak yang ditelantarkan tersebut tidak jelas geneologisnya (nasabnya), ayah dan ibunya tidak diketahui asal muasalnya. Mereka membuang buah hatinya karena didorong beberapa faktor yang beragam. Akan tetapi indikasinya sangat jelas, mereka tidak mampu untuk merawatnya karena keterbatasan ekonomi atau bertujuan untuk menutupi aib, karena anak itu merupakan hasil hubungan yang tidak semestinya.

Perilaku seks bebas, semakin meningkat seiring dengan semakin permisifnya anak muda terhadap pergaulan bebas, terutama di kalangan generasi muda. Bahkan usia remaja yang melakukan seks bebas, cenderung semakin muda pada perkembangan akhir-akhir. Perkembangan teknologi informasi dan komunikasi, dianggap sebagai salah satu pemicu utama perilaku seks bebas di kalangan remaja. Disamping tentunya semakin merosotnya nilai-nilai moral keagamaan dalam kehidupan remaja saat ini. 
Minimnya pengamalan ilmu yang mereka miliki sudah sampai pada level yang sangat memprihatinkan. Terjadinya perzinahan di mana-mana menyebabkan meningkanya aborsi dan penelantaran bayi-bayi yang tak berdosa. Anak tak berdosa sengaja dibuang oleh pasangan kekasih yang belum resmi menjadi ikatan suami istri yang sah.

Selain itu, hamil di luar nikah saat ini dianggap sesuatu yang biasa. Melahirkan anak tanpa suami dan perkawinan yang sah sudah kerap terjadi dalam masyarakat, dan buka dianggap sebagai aib yang besar. Semakin menurunnya nilai-nilai dalam masyarakat, menjadi pemicu kejadian sejenis karena sudah dianggap sebagai hal yang biasa.

Anak zina adalah anak yang dilahirkan dari seorang ibu yang dihasilkan dari hubungan yang tidak mengikuti aturan syara' atau hasil hubungan yang diharamkan. ${ }^{2}$ Terdapat beberapa hadits yang menjelaskan tentang eksistensi anak zina, diantaranya adalah:

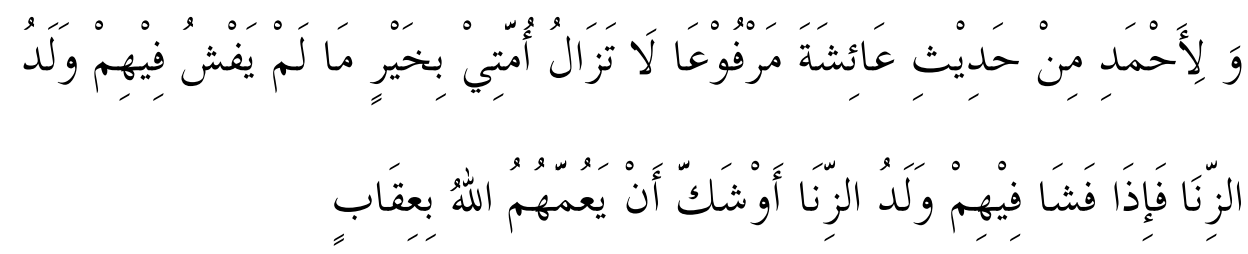

Artinya: Riwayat dari Ahmad dari hadits Aisyah RA, "Tak hentihentinya ummatku dalam kebaikan selama anak zina tidak tersebar di antara mereka, apabila ia menyebar di antara mereka maka tidak lama lagi Allah akan meratakan siksaan (musibah) pada mereka"3

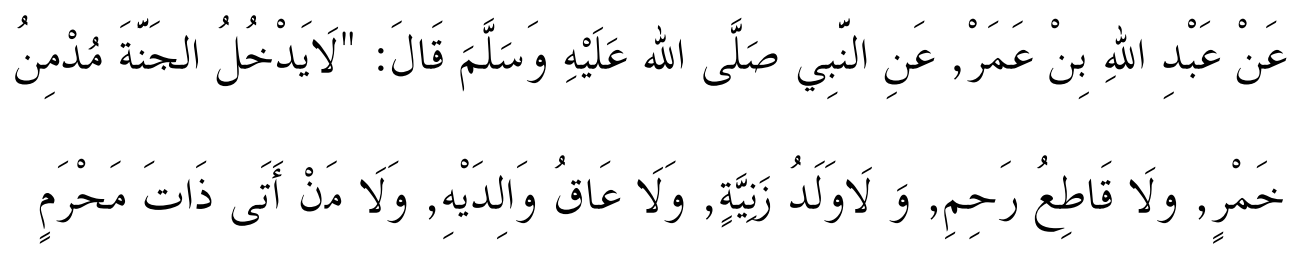

${ }^{2}$ Wahbah bin Musthafa al-Zuhaili. w. 1436 H Al-Fiq al-Islam, Juz. 2 h. 37

${ }^{3}$ Umar bin Ali bin Adil al-Hanbali. w. 880 H. Tafsir al-Lubab Libn Adil, Juz 15, h. 
Artinya: Dari Abdullah bin Umar, dari Rasulullah, ia bersabda, "Tidak akan masuk surga adalah pecandu khamr, orang yang memutus kerabat, anak zina, yang mendurhakai kedua orang tuanya, dan orang yang meniduri mahramnya" 4

\section{Anak Zina Masuk Surga}

Menyikapi hadits yang menvonis bahwa anak zina tidak akan masuk surga, sebagaimana dalam tulisan sebelumnya, Al-Hafidz Ibn Hajar mengatakan, "Ulama berpendapat bahwa hadits ini adalah shahih hanya saja butuh penakwilan-penakwilan. Takwilannya adalah anak zina tidak akan masuk surga apabila ia berbuat sebagaimana perbuatan kedua orang tuanya (melakukan zina), dan ada yang menakwili bahwa anak zina yang akan tidak masuk surga itu adalah orang yang selalu berbuat zina".

Dengan takwilan ini maka yang dimaksud dengan anak zina yang tidak akan masuk surga dalam teks hadits adalah pelaku zinanya atau anak zina yang berperilaku seperti orang tuanya, atau ditakwil dengan orang yang tak henti-henti berzina.

'Aisyah RA pernah ditanyakan tentang status anak zina pada hari kiamat, lalu beliau menjawab, "Anak zina tidak menanggung dosa kedua orang tuanya sedikitpun", dan beliau membaca ayat al-An'am:164

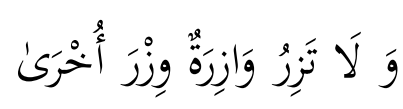

Artinya: Dan seorang yang berdosa tidak akan memikul dosa orang lain. ${ }^{5}$

Sedangkan Ibn Thahir mengira bahwa hadits yang menjelaskan tentang anak zina tidak akan masuk surga adalah maudhu' dan tidak jayyid ${ }^{6}$

\footnotetext{
Juz 16. h. 385

${ }_{5}^{5}$ Abu Muhammad Abdurrahman bin Muhammad Al-Razi Ibn Abi Hatim. w.327. H Tafsir Ibn Abi Hatim, Juz 5. h.465

${ }^{6}$ Ismail Utsman Zain al-Yamani al-Makki. w. 1414 H, Qurrah al-Ain, h. 191.
}

${ }^{4}$ Abu Bakar Ahmad bin Husain al-Baihaqi. w. 458 H Syu'bu al-Iman Li al-Baihaqi, 
Imam al-Bukhari dan an-Nasai menganggap hadits ini tergolong dhaif karena kontra dengan rumusan asal dalam firman Allah surat alAn'am:164.7 (Dan seorang yang berdosa tidak akan memikul dosa orang lain).

Beberapa penjelasan di atas, dapat memberi pemahaman bahwa anak zina tetap sama dengan kelompok lainnya, dan ia sangat berpeluang untuk menikmati hidup di surga apabila menjadi orang yang taat. Hadits yang menjelaskan anak zina tidak akan masuk surga statusnya hanya sebatas tahdzir, dan kita hanya bisa mengikuti beberapa komemtar ulama tentang eksitensi hadits itu dan tetap berdasarkan Kutub al-Sittah (Shahih al-Bukhari, Shahih Muslim, Sunan Abi Daud, Sunan al-Turmudzi, Sunan al-Nasa'i, Sunan Ibn Majah).

\section{Anak Zina dan Perkawinan}

Dalam Figh al-Islam dijelaskan anak zina tidak mempunyai sifat legalitas. anak yang dihasilkan dengan cara diluar nikah tidak ada hubungan geneologis atau nasab dengan pelaku zina. "Ayahnya" tidak mempunyai kekuasan padanya. Karena faktor-faktor yang bisa menyebabkan seseorang mempunyai wilayah atau kekuasaan ada empat, yaitu 1) al-Ubuwwah (kebapakan), 2) al-'Ashubah, 3) al-I'taq, dan 4) alShulthan. ${ }^{8}$ Apabila pelaku zina itu mengawinkan anak hasil hubungan gelap itu dengan cara dirinya yang menjadi wali atau mewakilkan pada orang lain, maka prosesi akad nikahnya tidak sah karena pelaku zina tersebut tidak mempunyai wilayah pada anak zina tersebut. Wakil yang ditunjuk olehnya tidak bisa mengawinkan karena proses pewakilan tidak sah. Kitab Nihayat al-Muhtaj menjelaskan bahwa di antara syarat orang yang mewakilkan adalah punya kekuasaan terhadap sesuatu yang akan diwakilkannya, seperti karena faktor milik, wilayah. ${ }^{9}$ Hakimlah yang berhak

7 Abul Faraj Abdurrahman bin Ali bin Muhammad al-Jauzi. w. $597 \mathrm{H} \mathrm{Al}$ Maudhu'at, Juz 3. h. 111

${ }^{8}$ Abu Bakar Utsman bin Muhammad Syatha al-Dimyathi. w. 1310 H I'anah alThalibin, Juz 3. h. 353 15, h. 277

${ }^{9}$ Syamsuddin Muhammad bin Ahmad al-Ramli. w. 1004 H. Nihayah al-Muhtaj. Juz 
menjadi wali nikah dari anak zina ini, karena hakim adalah wali dari orang yang tak punya wali. ${ }^{10}$

Madzhab Malikiyah berpendapat bahwa wilayah bisa saja terjadi sebab kafalah (menanggung). Barang siapa menanggung kelangsungan hidup seorang anak perempuan yang kehilangan orang tua dan keluarganya, dengan mendidik dalam waktu-waktu tertentu, maka ia mempunyai wilayah pada anak tersebut apabila memenuhi dua syarat yaitu: (1) anak perempuan itu tinggal bersamanya dengan waktu yang lama seperti 4 tahun atau 10 tahun. Si kafil (yang menaggung) harus mengganggap anak terlantar tersebut sebagai anaknya dalam segi kasih sayangnya. (2) Anak tersebut tergolong orang yang lemah atau hina, ia tak punya harta benda. Apabila syarat ini tak terpenuhi maka walinya adalah hakim. ${ }^{11}$

\section{Anak Zina dan Ibadah}

Bermakmum dalam salat berjamaah pada anak zina hukumnya tidak makruh, hanya saja hukumnya khilaf al-aula. Ada sebagian ulama memakruhkan dengan syarat proses berjamaah sejak dari awal salat atau sejak rakaat pertama, dan makmumnya bukan sama-sama anak zina. Apabila imam dan makmumnya sama-sama anak zina ulama sepakat bahwa hal tersebut tidak makruh. Dalam masalah ini dianggap sama dengan anak zina adalah anak yang tidak diketahui ayahnya (laqith) dan anak mula'anah. ${ }^{12}$ Kemakruhan imamah dari anak haram ini apabila masih ada orang lain yang bukan anak zina yang bisa menjadi imam. Jadi kemakruhan itu bukan dari faktor internal dari anak zinanya ${ }^{13}$. Selain madzhab Hambali sepakat bahwa kemakruhan terjadi apabila tidak ada orang lain yang pantas menjadi imam. Imam Hanafi membatasi kemakruhan anak zina menjadi imam salat apabila ia bodoh, dan apabila ia tergolong orang yang takwa dan alim maka hukumnya tidak makruh. ${ }^{14}$

${ }^{10}$ Zakariyya bin Muhammad bin Ahmad bin Zakariyya al-Anshari. w. 926 H. Syarh al-Bahjat Wardiyah, Juz 14.h. 237

${ }^{11}$ Alfq Ala Madzhab al-Arba'ah, Juz 4. h 19

${ }^{12}$ I'anah al-Thalibin, Juz 2. h. 56-57

${ }^{13}$ Hawasyi al-Syarwani, Juz. 2. h. 296

${ }^{14}$ Abdurrahman bin Muhammad 'Iwadl al-Jaziri. w. 1360 H AlFiq al-Islami, Juz 
Sedangkan Imam Malik membatasi kemakruhan ini apabila ia menjadi imam ratib. Pendapat yang terakhir ini ditolak oleh mayoritas ulama yang mengatakan hal itu tidak apa-apa. ${ }^{15}$

Terdapat banyak hal tentang anak zina apabila dikaitkan dengan ibadah dan hukum Islam, di antaranya adalah:

1. Apabila anak zina meninggal dunia maka wajib dimandikan dan di sholati. ${ }^{16}$ Sedangkan doa yang dibaca pada saat menyholati adalah "ya Allah jadikanlah ia sebagai simpanan pahala (dan penunjuk ke surga) bagi ibunya"17

2. Zakat fitrah anak zina dan anak li'an yang harus mengeluarkan adalah ibunya, karena nafkah anak tersebut harus ditanggung ibunya. ${ }^{18}$ Begitu pula tentang masalah aqiqah. ${ }^{19}$ Nasab anak haram ini diafiliasikan pada ibunya, karena ia tidak ada hubungan geneologis dengan "bapak" yang menjadi pelaku zina. ${ }^{20}$

3. Orang yang hamil di luar nikah, dan melahirkan seorang bayi lalu ia menyusui pada anak kecil lainnya, maka hubungan antara kedua bayi tersebut terjadi saudara radha' (susuan), dan ada sebagian ulama yang berpendapat bahwa keduanya tidak terjadi mahram karena susu anak haram dianggap tidak mempunyai sifat legalitas dalam Islam dan tidak mempunyai kemuliaan. ${ }^{21}$

4. Hukum waris bagi anak zina hanya bisa terjadi antara dia dengan "ibunya", sedangkan dengan "bapak" hukum tersebut terputus. ${ }^{22}$

5. Penyaksian dari anak zina dalam masalah zina dan had dapat diterima apabila anak tersebut tergolong orang adil 23

\footnotetext{
${ }^{15}$ Muhyiddin Yahya bin Syaraf al-Nawawi. w. 679 H . Al-Majmuk, Juz 4.h. 290

${ }^{16} \mathrm{Ibd}$, Juz 5. h. 267

${ }^{17}$ Zainuddin Ahmad bin Abdul Aziz al-Malibari. w. 987 H Fath al-Mu'ian, Juz 2. h. 146

18 Abu Bakar Utsman bin Muhammad Syatha al-Dimyathi. w. 1310 H I'anah alThalibin, Juz 2. h. 193 dan 233

${ }^{19}$ Sulaiman bin Umar bin Manshur al-'Ujaili al-Jamal. w. 1204 H Hasyiah al-Jamal, Juz 22. h. 207

${ }^{20}$ Tafsir al-Alusi, Juz 3.h. 494

${ }^{21}$ Zakariyya bin Muhammad bin Ahmad bin Zakariyya al-Anshari. w. 926. H Asna al-Muthalib, Juz 8. h. 32

${ }^{22}$ Muhyiddin Yahya bin Syaraf al-Nawawi. w. 679 H. Al-Majmuk,Juz 16.h. 105

${ }^{23}$ Ismail bin Yahya al-Muzani. w. 264 H. Mukhtashar al-Mazanni, Juz. 1.h. 311
} 


\section{Dosa di Tanggung Sendiri}

Anak zina merupakan hamba Allah yang harus dihormati, ia tidak mempunyai perbedaan dengan hamba-hamba Allah yang lain. Hanya saja ia dilahirkan dari orang-orang yang tidak bertanggung jawab. "Ayah dan ibunya" melakukan hubungan intim tanpa memegang nilai-nilai legalitas dari Islam. Dalam hal ini yang dosa adalah kedua pelaku tersebut. Bayi yang dilahirkan tidak akan menanggung dosa sedikitpun dari perbuatan zina, sebagaimana yang diutarakan oleh Sayyidah 'Aisya RA. Allah berfirman dalam surat al-an'am Ayat 164:

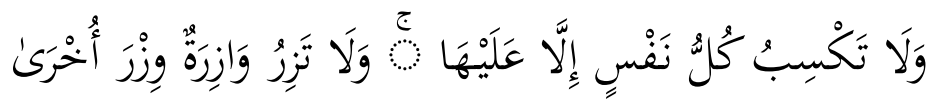

Artinya: Dan tidaklah seorang membuat dosa melainkan kemudharatannya kembali kepada dirinya sendiri; dan seorang yang berdosa tidak akan memikul dosa orang lain.

Maksud dari ayat tersebut adalah bahwa sesorang akan dibalas sesuai dengan perbuatannya, apabila ia berbuat kebaikan maka akan dibalas dengan kebaikan, dan apabila berbuat kejelekan maka ia akan dibalas pula dengan siksaan sesuai dengan perbuatannya itu. Masing-masing orang memikul dosanya sendiri-sendiri, dan tidak akan menanggung dosa orang lain, hal ini merupakan manifestasi dari sifat keadilan Allah. ${ }^{24}$

Abi Mulaikah berkata, "Ummi Amrin binti Aban bin Utsman meninggal dunia, pada saat mayat itu didatangkan Ibn Umar mendengar tangisan, lalu ia berkata "Hendaknya mereka berhenti menangis"! Karena Nabi SAW bersabda "Sesungguhnya mayat akan disiksa sebab tangisan orang yang masih hidup padanya". Lalu saya mendatangi Aisyah dan menceritakan kronologi itu dan beliau berkata, "Demi Allah kamu menyampaikan berita padaku dari seseorang yang tak pernah bohong, akan tetapi kamu salah persepsi, apakah ayat al-Quran tidak cukup bagimu? Yaitu ayat al-An'am:164“. ${ }^{25}$

${ }^{24}$ Ismail bin Umar bin Katsir al-Qurasyi. w. 774 H. Tafsir Ibn Katsir, Juz. 3. h. 383

${ }^{25}$ Jalaluddin Abdurrahman bin Abu Bakar al-Suyuthi w. 911 H Al-durru alMantsur, Juz. 4. h. 185 
Riwayat yang lain menerangkan bahwa Ibn Abi Mulaikah berkata, "Saya mendatangi jenazah Ummi Aban binti Utsman, di tempat itu ada Abdullah bin Umar dan Abdullah bin Abbas, lalu saya duduk di antara mereka, tak lama kemudian sekelompok wanita menangis. Ibn Umar berkata, "Ratapan orang yang hidup terhadap mayat adalah siksaan baginya". Abdullah bin Abbas berkata, "Saya keluar bersama Khalifah Umar, setelah sampai ke Baida' bertemu dengan Suhaib. Umar berkata pada Suhaib, "Wahai Suhaib sesungguhnya mayat itu disiksa sebab tangisan orang hidup padanya." Ibn Abbas berkata "Saya pergi ke Aisyah dan bertanya tentang itu", ia menjawab, "Semoga Umar dikasihani oleh Allah", hal ini Nabi Saw hanya bersabda dalam masalah Yahudiyah "Sesungguhnya Allah akan menambah siksaan orang kafir sebab ratapan sebagian keluarganya". ${ }^{26}$ Aisyah RA berkata, "Nabi Saw lewat bertemu Yahudiyah yang diratapi oleh keluarganya", Nabi saw bersabda "Mereka meratapinya dan sesungguhnya Yahudiyah itu disiksa dalam kuburnya" ${ }^{27}$

Hadits "Sesungguhnya mayat disiksa sebab tangisan orang yang hidup padanya" termentahkan dengan dua dalil, yaitu (1) Firman Allah surat alAn'am: 164

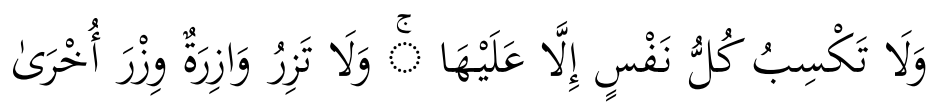

Artinya: Dan tidaklah seorang membuat dosa melainkan kemudharatannya kembali kepada dirinya sendiri; dan seorang yang berdosa tidak akan memikul dosa orang lain.

${ }^{26}$ Abu Bakar Abdullah bin Zubair al-Humaidi al-Qurasyi $\quad$ w. 219 H Musnad al-Hamidi, Juz 1. h. 144

${ }^{27}$ Ahmad bin Ali bin Hajar al-'Asqalani. w. 852 H. Fath al-Bari Libn Hajar,Juz 4.h. 331 
(2) Firman Allah QS. Al-Jatsiyah ayat 2628

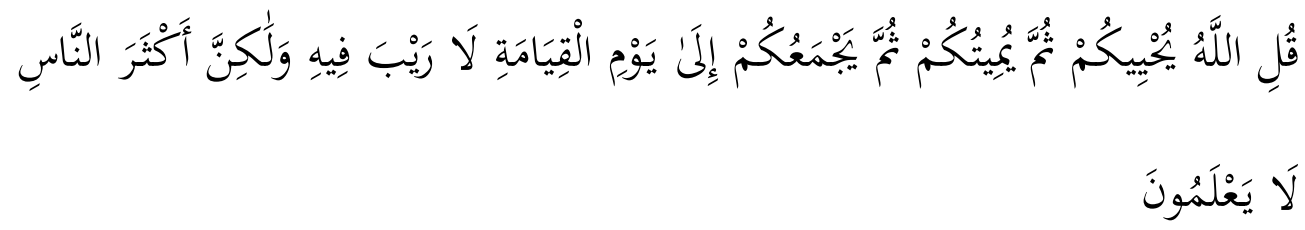

"Katakanlah: "Allah-lah yang menghidupkan kamu kemudian mematikan kamu, setelah itu mengumpulkan kamu pada hari kiamat yang tidak ada keraguan padanya; akan tetapi kebanyakan manusia tidak mengetahui".

Dalam surat at-Thur ayat 21

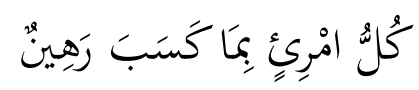

Artinya: "Tiap-tiap manusia terikat dengan apa yang dikerjakannya".

Hal ini dispesialisasikan pada perbuatan-perbuatan yang mengarah ke neraka. ${ }^{29}$ Sedangkan perbuatan-perbuatan yang baik, dapat mengalir berkahnya pada orang lain. Anak dan keturunan dari orang-orang yang shaleh akan dikumpulkan bersama mereka di surga meskipun perbuatannya tidak sampai pada derajat tersebut.

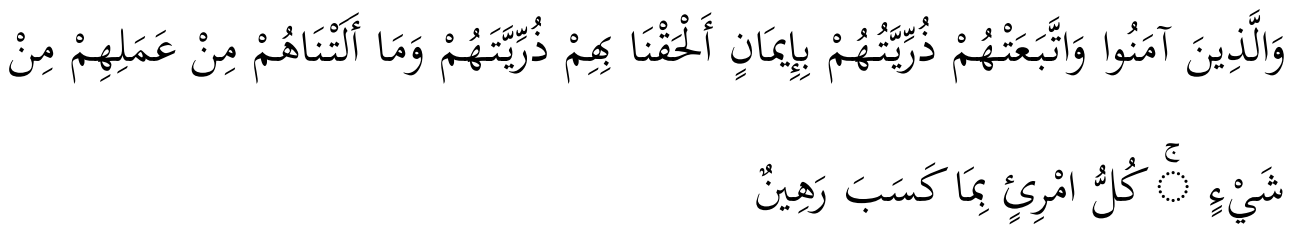

"Dan orang-orang yang beriman, dan anak cucu mereka yang mengikuti dalam keimanan, kami hubungkan anak cucu mereka dengannya, dan

${ }^{28}$ Abdullah bin Muslim bin Qutaibah al-Dinawari. w. 276 H Takwil Mukhtalaf alHadits, Juz. 1 h. 74

${ }^{29}$ Abul Faraj Abdurrahman bin Ali bin Muhammad al-Jauzi $\quad$ w. 597 H. Zad alMasir, Juz. 5.h. 431 
kami tiada mengurangi sedikitpun dari pahala amal mereka, tiap-tiap manusia terikat dengan apa yang dikerjakannya" (at-Thur ayat 21)

Anak zina dapat mengaktoalisasi dirinya dengan berperilaku seperti orang-orang yang takwa dan al-abrar. Sebagaimana penjelasan dalam kitab Qurrah al-Ain "Bagaimana pendapat Anda tentang anak zina di hari kiamat apabila di masa hidupnya berperilaku seperti orang-orang yang baik, tekun melakukan shalat, berpuasa, dan takut pada Allah? Jawabannya adalah, ia akan termasuk penduduk surga dan akan diperlakukan sebagaimana al-abrar oleh Allah." 30

Umar bin Khatthab berkata "31 "Muliakanlah dan berbaik hatilah pada anak zina". Ibn Abbas berkata "Anak zina itu adalah salah satu hamba Allah, apabila ia berbuat baik maka akan diberi pahala dan apabila berbuat jelek maka akan disiksa" 32 Sayyidah Aisyah berkata: "Merdekakanlah anak-anak zina itu, dan berbaik hatilah pada mereka".

\section{Simpulan}

Anak zina adalah anak yang dilahirkan dari seorang ibu yang dihasilkan dari hubungan yang tidak mengikuti aturan syara' atau hasil hubungan yang diharamkan. Anak yang dihasilkan dari hubungan tanpa nikah, mempunyai derajat yang sama di sisi Allah SWT sebagaimana hamba-hamba yang lain. Ia sangat berpeluang menjadi orang yang bahagia di dunia dan di akhirat apabila ia bisa mengaktualisasikan diri menjadi orang yang takwa.

Anak di luar nikah merupakan hamba Allah yang harus dihormati, ia tidak mempunyai perbedaan dengan hamba-hamba Allah yang lain. Hanya saja ia dilahirkan dari orang-orang yang tidak bertanggung jawab. "Ayah dan ibunya" melakukan hubungan intim tanpa memegang nilainilai legalitas dari Islam. Dalam hal ini yang dosa adalah kedua pelaku tersebut. Bayi yang dilahirkan tidak akan menanggung dosa sedikitpun

\footnotetext{
${ }^{30}$ Ismail Utsman Zain al-Yamani al-Makki. w. 1414 H Qurrah al-Ain, h. 191

${ }^{31}$ Mawahib al-Jalil. Juz. 7.h. 99

${ }^{32}$ Ibid, Juz 15. h. 224
} 
dari perbuatan zina, sebagaimana yang diutarakan oleh Sayyidah 'Aisya RA.

Terdapat banyak hal tentang anak zina apabila dikaitkan dengan ibadah dan hukum Islam, di antaranya adalah:

1. Apabila anak zina meninggal dunia maka wajib dimandikan dan di shalati. ${ }^{33}$ Sedangkan doa yang dibaca pada saat menyolati adalah "ya Allah jadikanlah ia sebagai simpanan pahala (dan penunjuk ke surga) bagi ibunya"34

2. Zakat fitrah anak zina dan anak li'an yang harus mengeluarkan adalah ibunya, karena nafkah anak tersebut harus ditanggung ibunya. ${ }^{35}$ Begitu pula tentang masalah aqiqah. ${ }^{36}$ Nasab anak haram ini diafiliasikan pada ibunya, karena ia tidak ada hubungan geneologis dengan "bapak" yang menjadi pelaku zina. ${ }^{37}$

3. Orang yang hamil di luar nikah, dan melahirkan seorang bayi lalu ia menyusui pada anak kecil lainnya, maka hubungan antara kedua bayi tersebut terjadi saudara radha' (susuan), dan ada sebagian ulama yang berpendapat bahwa keduanya tidak terjadi mahram karena susu anak haram dianggap tidak mempunyai sifat legalitas dalam Islam dan tidak mempunyai kemuliaan. ${ }^{38}$

4. Hukum waris bagi anak zina hanya bisa terjadi antara dia dengan "ibunya", sedangkan dengan "bapak" hukum tersebut terputus. ${ }^{39}$

5. Penyaksian dari anak zina dalam masalah zina dan had dapat diterima apabila anak tersebut tergolong orang adil 40

\footnotetext{
${ }^{33}$ Ibd, Juz 5. h. 267

${ }^{34}$ Zainuddin Ahmad bin Abdul Aziz al-Malibari. w. 987 H Fath al-Mu'ian, Juz 2. h. 146

35 Abu Bakar Utsman bin Muhammad Syatha al-Dimyathi. w. 1310 H I'anah alThalibin, Juz 2. h. 193 dan 233

${ }^{36}$ Sulaiman bin Umar bin Manshur al-'Ujaili al-Jamal. w. 1204 H Hasyiah al-Jamal, Juz 22. h. 207

${ }^{37}$ Tafsir al-Alusi, Juz 3.h. 494

${ }^{38}$ Zakariyya bin Muhammad bin Ahmad bin Zakariyya al-Anshari. w. 926. H Asna al-Muthalib, Juz 8. h. 32

${ }^{39}$ Muhyiddin Yahya bin Syaraf al-Nawawi. w. 679 H. Al-Majmuk,Juz 16.h. 105

${ }^{40}$ Ismail bin Yahya al-Muzani. w. 264 H. Mukhtashar al-Mazanni, Juz. 1.h. 311
} 


\section{DAFTAR PUSTAKA}

Abi Hatim, Abu Muhammad Abdurrahman bin Muhammad Al-Razi Ibn. w.327h. Tafsir Ibn Abi Hatim

Al-Anshari, Zakariyya bin Muhammad bin Ahmad bin Zakariyya. w. 926 H. Al-Ghurar al-bahiyyah fi-Syarh al-Bahjat Wardiyah

Al-Alusi, Syihabuddin Mahmud bin Abdillah al-Husaini. w. 1270 H. Ruh al-Ma'ani Tafsir al-Alusi

Al-'Asqalani, Ahmad bin Ali bin Hajar. w. 852 H. Fath al-Bari Libn Hajar

Al-Baihaqi. Abu Bakar Ahmad bin Husain. w. 458 H. Syu'bu al-Iman.

Al-Dimyathi. Abu Bakar Utsman bin Muhammad Syatha. w. 1310 H. I'anah al-Thalibin

Al-Dinawari, Abdullah bin Muslim bin Qutaibah. w. 276 H. Takwil Mukhtalafal-Hadits Juz. $1 \mathrm{~h} .74$

Al-Hanbali, Umar bin Ali bin Adil. w. 880 H. al-Lubab fi-ulum al-Kitab Tafsir Ibn Adil

Al-Jamal. Sulaiman bin Umar bin Manshur al-`Ujaili w. 1204 H. Hasyiah alJamal ala Syarh al-Manhaj

Al-Jauzi, Abul Faraj Abdurrahman bin Ali bin Muhammad.

w. $\quad 597$ H. Al-Maudhu'at.

Al-Jauzi, Abul Faraj Abdurrahman bin Ali bin Muhammad.

w. 597 H. Zad al-Masir

Al-Jaziri, Abdurrahman bin Muhammad 'Iwadl. w. 1360 H. Ala Madzhab al-Arba'ah

Al-figh

Al-Makki. Ismail Utsman Zain al-Yamani. w. 1414 H. Qurrah al-Ain

Al-Malibari, Zainuddin Ahmad bin Abdul Aziz. w. 987 H. Fath al-Mu'in 
Al-Nawawi. Muhyiddin Yahya bin Syaraf. w. 679 H. Al-Majmu' Syarh Muhadzdzab

Al-Muthi'i, Muhammad Najib. $\quad$ w. 1406 H. Al-Majmu' Syarh al Muhadzdzab

Al-Ramli, Syamsuddin Muhammad bin Ahmad. w. 1004 H. Nihayah al-Muhtaj ila syarh al-Minhaj

Al-Qurasyi, Ismail bin Umar bin Katsir. w. 774 H. Tafsir Ibn Katsir Juz.

Al-Qurasyi, Abu Bakar Abdullah bin Zubair al-Humaidi. w. 219 H. Musnad al-Humaidi

Al-Suyuthi, Jalaluddin Abdurrahman bin Abu Bakar. Durru al-Mantsur

w. 911 H. Al-

Al-Syarwani, Abdul Hamid bin Husain al-Dagestani.
Hawasyi al-Syarwani
Yahya, al-Muzani Ismail bin w. 264 H. Mukhtashar al-Muzani 